\title{
Potret Kontrak Bisnis Waralaba (Franchise) (Ketika Ruh Ditinggalkan Jasadnya)
}

\author{
Oleh: \\ Ery Agus Priyono \\ Fakultas Hukum Universitas Diponegoro \\ eryap@live.undip.ac.id
}

\begin{abstract}
Abstraksi
Waralaba merupakan suatu usaha yang sangat marak di Indonesia. Waralaba di Indonesia mulai dikenal di Indonesia sekitar tahun 1970-an dengan mulai masuknya franchise luar negeri seperti Kentucky Fried Chicken, Swensen, Shakey Pizza, dan kemudian diikuti dula oleh Burger King dan Seven Eleven. Saat ini hampir semua bidang bisnis tidak terbebas dari system yang di impor dari negeri paman sam ini. Hadirnya bisnis waralaba yang hampir meliputi semua kehidupan tidak ubahnya jasad yang tampil sangat menarik, selalu dilirik oleh pelaku usaha khususnya pemain baru. Waralaba tidak ada bedanya dengan bentuk perjanjian yang lain, yaitu ruhnya adalah kesepakatan (meeting of mind) yang saling menguntungkan (mutual accent). Hadirnya perjanjian baku yang menjadi bingkai bisnis waralaba menjadikan perjanjian waralaba sebagai Jasad yang meninggalkan ruhnya, bukan ruh yang meninggalkan jasadnya. Kajian dengan pendekatan normatif ini ingin memaparkan penerapan asas Kebebasan Berkontrak yang salah arah.
\end{abstract}

Kata kunci : Waralaba, perjanjian baku, kebebasan berkontrak. 


\section{A. Pendahuluan}

Waralaba sebagai contoh sebuah perjanjian yang dibuat secara tertulis ${ }^{1}$ merupakan suatu usaha yang sangat marak di Indonesia. Waralaba di Indonesia mulai dikenal di Indonesia sekitar tahun 1970-an dengan mulai masuknya franchise luar negeri seperti Kentucky Fried Chicken, Swensen, Shakey Pizza, dan kemudian diikuti dula oleh Burger

King dan Seven Eleven.. ${ }^{2}$ Saat ini hampir semua bidang bisnis tidak terbebas dari system yang di impor dari negeri paman sam yakni Amerika Serikat.

Banyak ahli bidang ini yang memberikan pengertian apa itu franchise, salah satunya Robert T.Justis \& Wiliam S. Vincent dalam Iman syahputra ${ }^{3}$ franchise atau waralaba didefinisakan sebagai ;

a method of distribution; in other words, a method of growing a business. A marketing channel of distribution whereby a company distributes its goods and services from itself to ultimate costumer. Franchise-generally speaking, this is defined as the right on license granted to an individual or group to market a company goods or services in particular territory. More specifically, a franchise a special type of license that usually has three elements.

Sebagai sebuah perjanjian yang tertulis yang berasal dari negeri asing waralaba harus tunduk pada hukum Indonesia (khususnya Buku III Hukum Perjanjian tentang Perikatan). Pasal 1319 KUH Perdata yang menjabarkan isi Pasal 1338 KUH Perdata Khususnya frase ....semua......telah menegaskan Semua persetujuan, baik yang mempunyai nama khusus, maupun yang tidak dikenal dengan suatu nama tertentu, tunduk pada peraturan umum yang termuat dalam bab ini dan bab yang lalu.

Masuknya waralaba dalam kasanah hukum perjanjian di Indonesia tidak lepas dari sifat buku tiga yang terbuka, sifat ini lahir dari rahim suatu asas yang sangat dijunjung

\footnotetext{
${ }^{1}$ Adrian Sutedi. 2008. Hukum Waralaba.Ghalia Indonesia.hlm. 89

${ }^{2}$ Tabloid WARALABA. ED. 06.Th IV 19 Oktober-1 November 2012

${ }^{3}$ Iman Sjahputra T. 2004. Franchising Konsep dan Kasus. Harvrindo. hlm. 4
}

\section{Jurnal Gema Keadilan}


tinggi oleh pelaku perjanjian, yaitu asas Kebebasan Berkontrak. Kebebasan berkontrak , suatu asas yang lahir pada zaman merebaknya aliran laisseiz faire yang dalam bidang ekonomi dipelopori oleh Adam Smith, guna mencegah campur tangan pemerintah yang berlebihan, merupakan ujud pemujaan terhadap faham individualisme. ${ }^{4}$

Perkembangan bisnis waralaba telah menggeser posisi asas Kebebasan Berkontrak yang awalnya merupakan perwujudan keadilan atas kepentingan para pihak yang didasari oleh kesepakatan (meeting of mind) yang saling menguntungkan (mutual accent), dalam perkembangan hanya menjadi topeng bagi pihak yang kuat untuk menekan pihak yang lemah.

\section{B. Pembahasan}

Asas kebebasan Berkontrak sebagai dasar pembentukan perjanjian waralaba, dalam prakteknya sering diselewengkan oleh pihak yang kuat sehingga sering menjadi sebab terjadinya penyimpangan dalam perumusan hak dan kewajiban oleh pihak yangkuat, sehingga merugian pihak yang lemah. ${ }^{5}$ Perlunya filter untuk mencegah ekses negatif perjanjian yang berbentuk baku dengan dalih penerapan Asas Kebeasan Berkontrak mendorong diterapkan Asas itikad. ${ }^{6}$

Asas kebebasan membuat kontrak dikenal dengan istilah "partij otonomie" atau " freedom of contract' atau "liberty of contract'. Istilah yang kedua lebih umum digunakan daripada istilah yang pertama dan ketiga. Asas kebebasan membuat kontrak ini adalah asas yang universal, artinya dianut oleh hukum kontrak di semua negara pada umumnya. ${ }^{7}$

Asas Kebebasan Berkontrak merupakan asas universal, Schmitthoff dalam Huala Adolf menegaskan

\footnotetext{
${ }^{4}$ Ridwan Khairandy. 2003. Itikad baik dalam kebebasab berkontrak., Jakarta, Pasca sarjana Fakultas Hukum UI, hIm. 43

${ }^{5}$ Ery Agus Priyono, Penerapan Asas Kebebasan Berkontrak dalam Perjanjian waralaba (suatu Kajian Normatif pada Perjanjian Waralaba Indomaret), Laporan Penelitian . Semarang, November 2014

${ }^{6}$ Ery Agus Priyono, 2017. Peranan Asas Itikad Baik dalam Kontrak Baku. Diponegoro Private Law Review Jurnal Bag. Keperdataan FH Undip. Jilid 1 (No.1, November). pp.13-21

${ }^{7}$ Sairam Bath, 2009, loc. Cit., hlm. 9, Willem M Vissert Hooft, 2005, loc. Cit, Mo Zhang, Chinese Contract Law, 2006 loc. Cit
}

\section{Jurnal Gema Keadilan}


"The autonomy of the parties will in the law of contract is the foundation on which an autonomous law of international trade can be built. The national souverign has,....no objection that in that area an autonomous law of international trade is develop by the parties, provided always that the law respect in every national jurisdiction the limitations imposed by public policy ${ }^{8}$

Berdasarkan Asas Kebebasan Berkontrak, maka orang boleh membuat atau tidak membuat perjanjian. Para pihak yang telah sepakat akan membuat perjanjian bebas menentukan apa yang boleh dan tidak boleh dicantumkan dalam suatu perjanjian. Kesepakatan yang diambil oleh para pihak mengikat mereka sebagai undang-undang (Pasal 1338 KUH Perdata). Penerapan asas ini memberikan tempat yang penting bagi berlakunya asas konsensual, yang mengindikasikan adanya keseimbangan kepentingan, keseimbangan dalam pembagian beban resiko, dan keseimbangan posisi tawar (bargaining position). ${ }^{9}$

Pasal 1320 merupakan pasal Pokok yang tidak bisa dikesampingkan (immutable) ${ }^{10}$, esensial, hal ini berbeda dengan sifat umum dari pasal-pasal dalam buku III KUH Perdata yang sifatnya mengatur (dalam istilah bahasa Belanda, disebut aanvulen recht) bukan hukum memaksa (dwingen recht) yang dalam istilah kepustakaan Amerika disebut contractual clauses. Ketentuan yang masuk dalam kelompok immutable clauses jumlahnya sedikit, akan tetapi tidak bisa dikesampingkan oleh para pihak, bahkan jika para pihak telah setuju dengan pengenyampingan tersebut. Berbeda dengan yang contractual clauses para pihak mempunyai kebebasan untuk merumuskannya sepanjang tidak dilarang oleh undang-undang, kekusilaan dan kepatutan.

${ }^{8}$ Clive M Schmitthoff, 1981, Comercial Law in a Changing Economic Climate, Sweet and Maxwel London. hlm. 22. dalam Huala Adolf, 2005, Hukum Perdagangan Internasional, Jakarta, Raja Grafindo Persada, , hlm. 15

9 Henry R Cheeseman, 1998, Business Law, The Legal, Ethical, and International Environment, Third Edition, Prentice Hall New Yersey, hlm.170

${ }^{10}$ Scot J Burnham. 1987. Drafting Contracts. The Michi Company Law Publisher. HIm. 4

\section{Jurnal Gema Keadilan}


Pasal 1320 KUH Perdata ini mengatur tentang syarat sahnya perjanjian yang terdiri dari 4 poin sebagai berikut :

1) Adanya kesepakatan kedua belah pihak

Sudikno Mertokusumo dalam Muhammad Syaifuddin berpendapat bahwa kesepakatan adalah persesuaian pernyataan kehendak antara satu orang atau lebih dengan pihak lainnya. Pernyataan para pihak-lah yang harus mengalami persesuaian, karena kehendak tidak dapat dilihat atau diketahui oleh orang lain. ${ }^{11}$ Persesuaian pernyataan kehendak tersebut dapat dinyatakan dengan menggunakan bahasa yang sempurna secara tertulis ataupun lisan maupun dengan menggunakan bahasa yang tidak sempurna, bahasa isyarat ataupun tidak menggunakan bahasa apapun (diam) selama pernyataan kehendak tersebut dapat dipahami dan diterima pihak lawan. $^{12}$

Kesepakatan dapat terjadi dengan berbagai cara tetapi cara terpenting yang dapat menghasilkan kesepakatan adalah melalui adanya penawaran dan penerimaan atas penawaran tersebut. ${ }^{13}$ Penawaran adalah pernyataan kehendak yang mengandung usul untuk mengadakan perjanjian sedangkan menurut J.H. Niewenhuis dalam Agus Yudha Hernoko, penerimaan adalah penyataan setuju dari pihak lain yang ditawari. ${ }^{14}$ Penawaran dan penerimaan dapat dilakukan secara tegas maupun tidak tegas, akan tetapi cara tersebut harus dapat dipahami oleh para pihak sebagai bentuk telah terjadinya penawaran dan penerimaan diantara mereka. ${ }^{15}$

2) Kecakapan untuk membuat suatu perikatan

\footnotetext{
${ }^{11}$ Muhammad Syaifuddin, Hukum Kontrak, Memahami Kontrak dalam perspektif filsafat, teori, dogmatik, dan praktik hukum (Seri Pengayaan Hukum Perikatan), (Bandung: Mandar Maju, 2012), hlm.112

${ }^{12}$ Ibid, hlm. 113

${ }^{13}$ Ahmadi Miru, Hukum Kontrak dan Perancangan Kontrak, (Jakarta: PT. Raja Grafindo Persada, 2008), hlm. 14

${ }^{14}$ Agus Yudha Hernoko, Agus Yudha Hernoko, Asas Proporsionalitas Dalam Kontrak Komersial, Laksbang Mediantama, Yogyakarta. 2008. , hlm. 162-163

${ }^{15}$ Ahmadi Miru, Op.cit., hlm. 14
}

\section{Jurnal Gema Keadilan}


Kecakapan untuk melakukan perbuatan hukum diartikan sebagai kemungkinan untuk melakukan perbuatan hukum secara mandiri yang mengikat diri sendiri tanpa dapat diganggu gugat. ${ }^{16}$ Pasal 1329 KUH Perdata memuat ketentuan definitif bahwa setiap orang adalah cakap membuat perikatan-perikatan, kecuali jika ia oleh undang-undang dinyatakan tidak cakap. Kualifikasi orang yang tidak cakap untuk membuat perjanjian menurut Pasal 1330 KUH Perdata. ${ }^{17}$

3) Suatu hal tertentu

Suatu hal tertentu adalah prestasi yang menjadi pokok kontrak yang bersangkutan. ${ }^{18}$ Beberapa syarat mengenai objek perjanjian, adalah ${ }^{19}$ :

a) Objek harus tertentu atau dapat ditentukan

b) Objek dapat diperdagangkan

c) Objek mungkin dilakukan

d) Objek dapat dinilai dengan uang

4) Suatu sebab yang halal.

Sebab atau kausa adalah tujuan dari perjanjian. ${ }^{20}$ Pasal 1335 KUH Perdata menegaskan bahwa suatu perjanjian yang dibuat tanpa sebab atau dibuat dengan sebab yang palsu atau terlarang tidak mempunyai kekuatan. Selain Pasal 1335 KUH Perdata, Pasal 1337 KUH Perdata menegaskan bahwa suatu sebab adalah terlarang, apabila dilarang oleh undang-undang, atau apabila berlawanan dengan kesusilaan baik atau ketertiban umum. Oleh karena itu dapat disimpulkan bahwa suatu perjanjian batal atau tidak mempunyai kekuatan hukum mengikat apabila perjanjian

\footnotetext{
${ }^{16}$ Agus Yudha Hernoko, Op.cit., hlm. 183- 184

${ }^{17}$ Ibid, hlm. 191

${ }^{18}$ Ibid

${ }^{19}$ Herlien Budiono, Ajaran Umum Hukum Perjanjian dan Penerapannya di Bidang Kenotariatan,(Bandung: Citra Aditya Bakti, 2010), hlm. 108

${ }^{20}$ R. Setiawan, Op.cit., hlm. 62
}

\section{Jurnal Gema Keadilan}


itu tidak memiliki kausa, kausanya palsu, dan kausa bertentangan dengan undangundang, kesusilaan dan ketertiban umum.

Keempat syarat di atas dapat dibagi ke dalam dua kelompok yaitu syarat subjektif dan syarat objektif. Syarat subjektif adalah suatu syarat yang menyangkut pada subjek perjanjian. Syarat ini meliputi syarat kesepakatan dan syarat kecakapan. Syarat objektif adalah syarat yang menyangkut pada objek perjanjian. Syarat ini meliputi syarat suatu hal tertentu dan suatu sebab yang halal. ${ }^{21}$

Suatu ketentuan dalam undang-undang jelas akan menimbulkan akibat hukum apabila salah satu syarat tidak terpenuhi. Apabila syarat subjektif tidak terpenuhi maka akibat hukumnya adalah perjanjian tersebut dapat dibatalkan, artinya perjanjian tersebut dapat dimintakan pembatalannya kepada hakim melalui pengadilan. Apabila syarat objektif tidak terpenuhi maka akibat hukumnya adalah perjanjian tersebut menjadi batal demi hukum, (void/nieteg) dianggap tidak pernah ada. Pasal 1337 KUH Perdata menjelaskan causa (sebab) yang tidak halal (terlarang), jika sebab itu dilarang oleh undang-undang atau bila sebab itu bertentangan dengan kesusilaan atau dengan ketertiban umum, artinya sejak awal tidak pernah lahir perjanjian sehingga tidak ada akibat hukum apa pun. ${ }^{22}$

Buku III KUH Perdata yang mengatur tentang perikatan termasuk di dalamnya perjanjian merupakan ketentuan yang sarat (penuh) dengan nilai-nilai moral yang menjadi asas-asas yang mendasari lahirnya dan pelaksanannya suatu perjanjian, yang kemudian diformalkan dalam beberapa pasal.

Nilai-nilai moral yang mendasari lahirnya perjanjian adalah sebagai berikut;

1. Bahwa perjanjian tidak boleh bertentangan dengan undang-undang, ketertiban umum,

\footnotetext{
${ }^{21}$ A. Qirom Syamsudin Meliala, Pokok-Pokok Hukum Perjanjian Beserta Perkembangannya, (Yogyakarta: Liberty, 1985), hlm. 11

${ }^{22}$ I.G. Rai Wijaya, Merancang Suatu Kontrak (Contract Dreafting) Edisi Revisi Teori \& Praktik, (Jakarta : Kesaint Blanc, 2007), hlm. 55
}

\section{Jurnal Gema Keadilan}


kesusilaan dan kepatutan (KUH Perdata : Pasal 1320 angka 4 dan Pasal 1337)

2. Bahwa Perjanjian harus didasarkan atas kesepakatan, selanjutnya disebut asas konsensual (KUH Perdata: Pasal 1320 angka 1 dan 1338)

3. Bahwa Perjanjian dibuat dengan kehendak bebas dari para pihak, asas kebebasan berkontrak (KUH Perdata : Pasal 1338)

4. Perjanjian sebagai hasil kesepakatan mengikat para pihak seperti undang-undang dan tidak bisa dibatalkan secara sepihak, asas kekuatan mengikat (pacta sun servanda) KUH Perrdata : Pasal 1338)

5. Perjanjian itu harus dilaksanakan dengan itikad baik, asas itikad baik (dipahami sebagai pada waktu membuat perjanjian harus dilandasi kejujuran (itikad baik subyektif) dan pada waktu pelaksanaan harus mengacu pada hasil kesepakatannya. Ketidak jelasan rumusan perjanjian yang menyebabkan kesulitan dalam pelaksanaan , dilaksanakan berdasarkan kebiasan yang berlaku (KUH Perdata Pasal 1339)

Tidak dapat dipungkiri bahwa ketentuan perjanjian sebagaimana diatur dalam buku III KUH Perdata yang merupakan hokum colonial berlaku di Indonesia (Hindia Belanda ) berdasarkan asas konkordansi mulai tahun 1848, yang pembuatannya didasarkan pada paham penghargaan terhadap martabat individu (individualisme) dapat memberikan kemafaatan sebesar besarnya bagi para pihak . Hukum ini telah memberikan rasa keadilan dengan prinsip-prinsip di atas. Hukum jika diibaratkan sebagai sesosok tubuh maka tidak hanya tubuh dengan tulang belulang yang kokoh, kuat tetapi juga memancarkan keindahan dari dalam ( berupa nilai-nilai intrinsic, nilai-nilai konstitutif)

Zaman berubah, sejalan dengan waktu Perjanjian (termasuk perjanjian waralaba) telah bergeser dari asas-asas di atas atau sengaja digeser kemakna yang berbeda. Legal formal prinsip-prinsip perjanjian masih ada tetapi maknanya telah tiada, Kesepakatan sekedar dimaknai " take it or leave it " tanpa kebebasan, tanpa ada proses menuju kesepakatan yang esensial.

\section{Jurnal Gema Keadilan}


Suatu kontrak, secara tradisional terjadi berdasarkan asas kebebasan berkontrak, melalui suatu proses negosiasi diantara yang seimbang diantara mereka ${ }^{23}$, namun pada dewasa ini kecenderungan makin memperlihatkan bahwa banyak kontrak di dalam transaksi bisnis yang terjadi bukan melalui proses negosiasi yang seimbang di antara para pihak. Kontrak itu terjadi dengan cara pihak yang satu telah menyiapkan syaratsyarat baku pada suatu formulir kontrak yang sudah dicetak dan kemudian disodorkan kepada pihak lainnya untuk disetujui dengan hampir tidak memberikan kebebasan sama sekali kepada pihak lainnya untuk melakukan negosiasi atas syarat-syarat yang disodorkan. Kontrak yang demikian itu dinamakan kontrak standar atau kontrak baku atau kontrak adhesi. ${ }^{24}$

Kebebasan berkontrak telah menjadi kedok bagi para perancang kontrak. baku Asas ini juga membuat orang/pihak yang kuat bisa memaksakan kehendaknya terhadap pihak yang lemah, sehingga cita-cita kebebasan berkontrak yang awalnya memberikan keseimbangan hukum, keseimbangan kepentingan dan juga keseimbangan dalam posisi tawar, menjadi sarana penekan terhadap pihak yang lemah, oleh karena itu Pasal 1337 KUH Perdata memberikan batasan pada praktek penerapan asas tersebut dengan menegaskan "sebab" perjanjian itu harus halal artinya tidak dilarang undang-undang, tidak bertentangan dengan kesusilaan yang baik atau ketertiban umum .

Kebebasan merupakan hak asasi yang diakui di dalam Undang-Undang Dasar 1945..$^{25}$ Kebebasan yang diberikan kepada para pihak dalam membuat perjanjian, bukanlah kebebasan yang tidak ada pembatasannya. Pasal $1320 \mathrm{KUH}$ Perdata, Pasal 1337 KUH Perdata, Pasal 1338 KUH Perdata, dan Pasal 1339 KUH

${ }^{23}$ Herlien Budiono, 2007, Kumpulan Tulisan Hukum Perdata di Bidang Kenotariatan, Citra Aditya Bakti, Bandung, hlm. 1

${ }^{24}$ Sutan Remy Sjahdeini, 1993, Kebebasan Berkontrak dan Perlindungan yang Seimbang Bagi Para Pihak dalam Kontrak Kredt Bank di Indonesia, Institut Bankir Indonesia, Jakarta, hlm. 66

${ }^{25}$ Muladi. 2007, Hak Asasi Manusia, Hakekat, Konsep dan Implikasinya dalam Perspektif Hukum dan Masyarakat, PT Refika Aditama, Bandung hlm. 12

\section{Jurnal Gema Keadilan}


Perdata merupakan bukti nyata adanya pembatasan itu, dengan kata lain bahwa di dalam Asas Kebebasan Berkontrak itu terkandung "tanggung jawab", terlebih lagi di negara yang landasan idiilnya Pancasila ${ }^{26}$

Secara bahasan nilai (asas) ketika ilmu, perjanjian (jasad ) telah meninggalkan ruhnya (nilai-nilai intrinsic, asas ), di mana realita dipahami secara naïf, kebenaran diukur dari realita inderawi semata, penolakan secara keras dan total atas nilai-niali metafisik, maka tulang belulang yang nampak kokoh itu telah kehilangan nilai-nilai esensialnya, nilai-nilai moral yang menjadikannya sosok itu senantiasa memancarkan keindahan, keindahan bagi semua orang. Perjanjian menjadi alat menindas orang.

\section{Kesimpulan :}

Perjanjian waralaba yang pada umumnya berbentuk baku telah menghilangkan ruh adanya perjanjian itu sendiri yaitu kesepakatan (meeting of mind) yang saling menguntungkan (mutual accent). Hadirnya perjanjian baku yang menjadi bingkai bisnis waralaba menjadikan perjanjian waralaba sebagai Jasad yang meninggalkan ruhnya, bukan ruh yang meninggalkan jasadnya.

\footnotetext{
${ }^{26}$ Mariam Darus Badrulzaman, 2001, Kompilasi Hukum Perikatan, Bandung, Citra Adtya Bakti, hlm. 84
}

\section{Jurnal Gema Keadilan}




\section{Pustaka Rujukan}

A. Qirom Syamsudin Meliala, Pokok-Pokok Hukum Perjanjian Beserta Perkembangannya, Yogyakarta, Liberty, 1985

Adrian Sutedi. 2008. Hukum Waralaba.jakarta. Ghalia Indonesia.

Ahmadi Miru, 2008, Hukum Kontrak dan Perancangan Kontrak, (Jakarta, PT. Raja Grafindo Persada.

Agus Yudha Hernoko, 2008, Asas Proporsionalitas Dalam Kontrak Komersial, Laksbang Mediantama, Yogyakarta.

Clive M Schmitthoff, 1981, Comercial Law in a Changing Economic Climate, Sweet and Maxwel London.

Ery Agus Priyono, 2017. Peranan Asas Itikad Baik dalam Kontrak Baku. Diponegoro Private Law Review Jurnal Bag. Keperdataan FH Undip. Jilid 1 (No.1, November). pp.13-21

Ery Agus Priyono, Penerapan Asas Kebebasan Berkontrak dalam Perjanjian waralaba (suatu Kajian Normatif pada Perjanjian Waralaba Indomaret), Laporan Penelitian . Semarang, November 2014

Henry R Cheeseman, 1998, Business Law, The Legal, Ethical, and International Environment, Third Edition, Prentice Hall New Yersey.

Herlien Budiono, 2007, Kumpulan Tulisan Hukum Perdata di Bidang Kenotariatan, Bandung, Citra Aditya Bakti.

Herlien Budiono, . 2010, Ajaran Umum Hukum Perjanjian dan Penerapannya di Bidang Kenotariatan,Bandung, Citra Aditya Bakti.

Huala Adolf, 2005, Hukum Perdagangan Internasional, Jakarta, Raja Grafindo Persada,

I.G. Rai Wijaya, 2007, Merancang Suatu Kontrak (Contract Dreafting) Edisi Revisi Teori \& Praktik, Jakarta, Kesaint Blanc.

Iman Sjahputra T. 2004. Franchising Konsep dan Kasus. Bandung. Harvrindo

\section{Jurnal Gema Keadilan}


Jujun S Suriassumantri. 2010. Filsafat Ilmu Sebuah Pengantar Populer. Jakarta. Pustaka Sinar Harapan.

Liek Wilardjo. 1990. Realita dan Desiderata. Yogyakarta. Duta wacana University Press Liek Wilardjo. Tacit dan Kiat

M. Syaifuddin. 2012., Hukum KOntrak, Memahami Kontrak dalam Perspektif Filsafat, Teori, Dogmatik dan Praktek Hukum. Bandung. Penerbit CV. Mandar maju

Muladi. 2007, Hak Asasi Manusia, Hakekat, Konsep dan Implikasinya dalam Perspektif Hukum dan Masyarakat, Bandung, PT Refika Aditama.

Ridwan Khairandy. 2003. Itikad baik dalam kebebasab berkontrak., Jakarta, Pasca sarjana Fakultas Hukum UI.

Scot J Burnham. 1987. Drafting Contracts. The Michi Company Law Publisher.

Sutan Remy Sjahdeini, 1993, Kebebasan Berkontrak dan Perlindungan yang Seimbang Bagi Para Pihak dalam Kontrak Kredt Bank di Indonesia, Jakarta, Institut Bankir Indonesia

\section{Tabloid :}

WARALABA. ED. 06.Th IV 19 Oktober-1 November 2012 , dan ed. 11 Th. V 3-16 Januari 2014

Tanpa nama :

Dikotomi Sain dan Agama

Biografi Francis Bacon

Kekuatan Pengimbang

Problem Nilai dalam Ilmu

\section{Jurnal Gema Keadilan}

